\begin{tabular}{|c|l|}
\hline \multirow{2}{*}{$\begin{array}{c}\text { TOURISM } \\
\text { AND }\end{array}$} & Journal of Tourism\&Management Research \\
MANAGEMENT & ISSN: 2149-6528 \\
AN NTIERNATONAL JOURNAL & 2021 Vol. 6, Issue.1 \\
& http://ottomanjournal.com/index.html \\
\hline
\end{tabular}

\title{
Comparative Study of the Performance of Selected Local Tourism Business Operations in the Economy of Kisumu/Kenya: A Multivariate Analysis of Variance and Discriminant Analysis
}

\begin{abstract}
Accommodation sector is important in the transmission of tourism economic impacts to destinations` economies. Though a number of studies have been done on the role of quality accommodation in enhancing competitiveness and growth of tourism in different destinations, little information exist on the relative performance of different types of tourism businesses in the local economy. Therefore, the purpose of the study was to find out whether tourism enterprises were different in their performance in the local economy of Kisumu County and analyze factors contributing to the differences. Thus, a cross section survey of 106 randomly selected tourism enterprises was conducted and data collected using self-administered questionnaires. Multivariate analysis of variance was used to determine performance differences in groups of tourism enterprises and descriptive discriminant analysis was used to find out pattern in their differences. It was established that there were differences in performance among tourism enterprises and that the key factors contributing to their differences were the number of suppliers they engaged in a week and in their expenditure on locally produced inputs as proportion of their total expenditure. It was concluded that right balance be struck in facility investments with some bias towards guest houses, clubs and restaurants.
\end{abstract}

Keywords: Economy of Kisumu, tourism enterprises, local procurement, differentiating performance, profitability, growth

JEL Classification: L2, L53, Z32

Submitted: 07.01.2020; Accepted: 15.04.2021

Mathias Mwalo Amata, PhD Candidate. Maseno University. P.O. Box 3848 - 40100 Kisumu, Kenya.

Tel. +254 711673984

Email: amatamwalo2014@yahoo.com 


\section{Introduction}

The accommodation is a sub-sector of tourism industry that plays a crucial role in improving tourism economic impact on local economies of destination areas. The economic impact of accommodation can be sustained if appropriate tourists facilities of right quality are established to promote tourism development in a destination (Lickorish, 1997). The quality of accommodation sub - sector not only affect the overall tourism experience, but also accounts for the highest proportion of tourists`expenditure compared to such other sub - sectors of tourism as attraction, transportation, and ancillary services (Fletcher, Fyall, Gilbert \& Wanhill, 2018; Sharpley, 2005).

Although previous researchers have greatly focused on the economic importance and challenges of accommodation sector in national and the local economies of various nations (Fletcher et al., 2018; Meyer, 2007), no sufficient investigation has been done to compare the performance of such different type of tourism operation establishments as restaurants, clubs, guest houses, lodges and hotels in creating economic linkages with businesses owned by local people in Kisumu County. Local tourism businesses are micro, small and medium-sized enterprises which operate in Kisumu County and supply tourist industry with different inputs ranging from agricultural products to services. Micro, small and medium enterprises account for $66 \%$ of 1.3 million enterprises in rural areas and it is the fastest growing sector in Kenya (Ministry of Labour and Human Resource Development, 2005). Also, the sector is both central in sustainable development and it is indispensable in the prosperity of rural areas as tourists`destinations (Ateljic \& Page, 2009; Ministry of Devolution and Planning, 2013)

The contribution of the current study will be first, to create new awareness of the types of tourism enterprises which have the greatest impact on local economy of Kisumu County and, secondly, create understanding of the key bases upon which they are differentiated from each other in terms of performance in the local economy. A number of research studies on economic importance of accommodation sector have been reviewed and followed with a cross-sectional survey of experiences of different types of tourism enterprises operating in Kisumu County. Thus, the study used a random sample of 106 tourism enterprises which included limited range of facilities such as hotels, restaurants, clubs, guest houses and lodges whose location are restricted to Kisumu County. The paper is structured into three key areas: The first area covers review of relevant previous studies on role of accommodation establishment in both local and national economy. The second is the methodologies which encompass cross-section survey of tourism enterprises, data collection technique and analysis of data collected. The last section covers discussion of the results in the context of extant knowledge and implications of the findings on policy and theory.

\section{Literature Review}

\subsection{The Service Profit Chain Theory and Accommodation Enterprises}

The theory underscores the centrality of joint effect of capacitated and supported frontline employees of a service business, such as accommodation facility, and customers attitude in the realization of effective service delivery (Kotler, Bowen \& Make 2014). The service profit chain identifies profitability and growth as function of customers loyalty, employees satisfaction, value of service offered, support services and policies directed towards improving employees` productivity (Heskett, Sasser, \& Schlesinger 1997).

According to the theory, the loyalty and satisfaction of both employees and customers contribute to enterprise`s profitability and growth. Also, employees` capability, level of service and quality of employees`output is affected by the service delivery system and operation strategy (Heskett et al., 1997). Employees' productivity and quality of their output will affect value of services given to customers. Thus, customers who get more value for money from employees get satisfied. The satisfaction is registered in repeat business with the enterprise and positive referrals leading to profitability and growth (Heskett et al., 1997). The 
converse is true for customers who get mediocre value from unskilled and demotivated employees.

Lastly, the theory also identifies management as a factor which moderates relationship between employees` productivity and quality of service leading to customer satisfaction (Heskett et al., 1997). The theory is useful in the current context as it explains the tourism enterprises` internal dynamics behind the delivery of growth and profitability which, in turn, determines the enterprises` potential to create economic linkages with local businesses.

\subsection{Role of Accommodation Sector in the Local Economy}

A study based on historical longitudinal approach by Magombo, Rogerson and Rogerson (2017) which intended to examine the unfolding evolution of accommodation services as a factor of enhancing tourism destination competitiveness in Malawi found out that the existence of different forms of accommodation of right quality and offered at competitive rates is a prerequisite to growth of tourism in any destination (Christie et al. 2013; Dwyer \& Kim 2003; Enrst \& Young 2011; Ritchie \& Crounch 2003). They supported their observation with various illustrations including: First, refurbishing accommodation sector enhanced the Tanzania competitiveness to attract international leisure tourists (Salazar 2008). Secondly, development of different forms of accommodation and their upgrading in quantity and quality made Ghana accommodation sector internationally competitive (Mensah 2013). Lastly, Magambo and Rogerson (2012) (cited in Magombo, Rogerson, and Rogerson, 2017) observed that the establishment of improved chain of hotels boosted the competitiveness of Malawi tourism and its role in national economic development. In contrast, a study based in coastal regions of Kenya by Mshenga and Owuor (2009) that sought to determine proportion of hotels inputs purchased from small and medium enterprises (SMEs), established that meat, milk, fish, poultry products, fruits and vegetables as key commodities traded by small scale suppliers either directly or through middlemen. Moreover, beverages and security services were mostly provided by large distributors and established security firms respectively, but $48 \%$ of hotel furniture was procured from local SMEs (Mshenga \& Owuor, 2009). Similar to a study by Magombo, Rogerson and Rogerson (2017), Rogerson and Rogerson (2014) carried out a study in South Africa aimed at establishing the role of the accommodation sector as a basis of tourism - led local development in rural areas and small towns. The finding was that food purchases by hotels from Durban and it's environ did not have any positive bearing on local poverty reduction (Pillay \& Rogerson 2013). This was partly attributed to limited local capacity to furnish necessary skills and other supplies demanded by tourist enterprises, thus created avenues for income leakages that is common in many developing world where tourism is vibrant (Nepal 2010; Rogerson \& Rogerson 2014). The finding of Rogerson and Rogerson (2014) is in conformity with many studies that have previously found out that a number of tourism accommodation tended to prefer cheapest, reliable, accessible food supply sources which are also of high quality (Hunt \& Rogerson, 2013; Rogerson 2012; Torres, 2003). The implication of the study was that local economic development policies are relevant in promoting linkages between agriculture and tourism (Rogerson \& Rogerson 2014). Lastly, in order to establish spatial dimension of the impact of employment in tourism accommodation sector on local livelihood, Adiya, Veneste and Ahebwa (2014) carried a survey of 126 employees in 32 accommodations in Western Uganda. They established that accommodation sector is important in providing employments in many developing countries and confirmed that accommodation has central position in tourism value chain of rural economies of developing countries (Meyer 2007). It was further established that accommodation account for $78 \%$ of pro poor jobs in Uganda tourists` industry and enhanced procurement of local supplies. Lastly, according to Christensen \& Hatman (2005) (cited in Adiya et al., 2014) tourism income, though comparatively low in developing countries, represented the most dominant cash flow in the households budget for majority of 
households. The study also confirmed a previous finding by Marcouiller and Xia (2008) that spatial differences in income inequalities were extant between rural and urban tourism context.

Different methodologies were adopted by researchers in different research contexts with varying outcomes. Mshenga and Owuor (2009) adopted an explorative survey design targeting 49 hotels with bed capacity of 40 and above. Data was collected from procurement managers using interview and finally descriptive statistics was used in data analysis which undermined generalization of the findings. Last but not least, Rogerson and Rogerson (2014) study was basically an audit and analysis of nature tourism based on internet searches. However, the analysis was done using descriptive statistics thus, lowering its external validity. Lastly, Adiya et al. (2014) study was a survey of 126 employees working in 32 accommodations. The study adopted a two-stage sampling to get a representative sample in which employee of each accommodation was contacted through hotel manager and subsequent respondents secured using snowball sampling. Semi-structured interview was applied in collecting data. It is interesting to note that of all the four studies, Adiya et al. (2014) appears to be based on a most robust methodological approach. Also, the study by Adiya et al. (2014), Mshenga and Owuor (2009), and Rogerson and Rogerson (2014) are related because they are all biased towards tourism backward linkages with local economy. However, the study by Magombo, Rogerson and Rogerson (2017) adopted a historical longitudinal approach in assessing geographic pattern of accommodation services in Malawi and relied on colonial and pre-independence policy document. The study made some contribution by addressing gaps in locational attributes of accommodation sector in Malawi, but deviated from the rest as its main focus was on the role of accommodation sector in enhancing destinations' international competitiveness. Finally, all the aforementioned studies did not make any significant contribution in relation to comparative analysis of performance of different types of tourism enterprises on local economy - a gap which the current study serve to fill.

\subsection{Significance of Guest Houses in the Local Economy}

Guest house is defined as a facility that offer personalized services, greater quietude and more opportunity to interact with local people (Henning, 2007), or a premise from which guests are provided with sleeping accommodation and limited services for monetary consideration. Alternatively, it is seen as an existing home, a renovated home or a building that has been specifically designed as a residential dwelling to provide overnight accommodation, together with public areas for exclusive use for its guests (George, 2012).

Various researchers studied economic contribution of guest house from different perspectives but had mixed findings on the constraints faced and role played by guest houses in the local economy. An exploratory study done by Chia and Muiz (2020) aimed at revealing the nature of the business and challenges faced by guest house business in Meldives found out that though guest houses are important to tourist market and local economy, but their operations are constrained by a number of challenges. For instance, the limitations of budget make guest houses to mostly rely on online agents for promotion (Chia $\&$ Muiz 2020). Further, the study found out that competition, state of infrastructure affected guest and lack of policies and regulation for controlling tourism development affected guest house businesses in Maldives (Chia \& Muiz, 2020; Magombo, Rogerson \& Rogerson 2017). Despite the foregoing constraints, guest house offer personalized services, greater quietude and more opportunity to interact with local people (Henning 2007). Also, operating guest house not only provides a source of income to local people and improve their quality of life but also enhance local economic development and reduce rural to urban migration (Zhao 2019). Likewise, different types of accommodation facilities portrayed different images regarding affordability and experience (Chia \& Muiz 2020). Prior to the study of Chia and 
Muiz (2020), Portolan (2012) had investigated the impact of accommodation on economic development of tourist destination in Dubrovnik - Neretva County. The aim of the study was to estimate the importance of private accommodation in the development of tourist destination on regional level. The key insights were that a large proportion of private accommodation users were well educated and most of them depended on friends and relatives for information. Also, visitors who stayed longer in private accommodation spent more on food than those who stayed in camps and tourist establishments - a finding which was later confirmed by Chia and Muiz (2020). It was concluded that private accommodation receives substantial tourist income which creates direct, indirect and induced effect in destination economy. A similar study focusing on the contribution of guest houses to local economic development through procurement of locally produced product in the Eden district of South Africa by Ramukhumba and Ferreira (2016) found out that guest houses make positive contribution to local economic development, because majority of guest houses depend on locally produced product and inject between R 5000 and R 10000 per month in the local economy.

The foregoing studies provided important insights regarding the business dynamics facing guest house business in the specific economic contexts in which the studies were domiciled. As to whether the findings indicate the general guest houses' business experiences in Sub Sahara Africa depend on the methodologies adopted by the researchers. The key similarity of studies done by Chui and Muiz (2020), Portolan (2012) and Ramukhumba and Ferreira (2016) was in their bias towards a specific type of accommodation establishment namely guest houses. However, they deviated from one another on specific focus of interest and on study methodologies. While the reliability and validity of Chui and Muiz (2020) study was enhanced by their adoption of face to face indepth interview of informants, the study may be biased towards the selected informants as the size of actual sample used in the study was not based on subjective criteria which applied in qualitative methods, and the respondents in the study were selected purposively based on snowball sampling. In contrast, Portolan (2012) study differed from that of Chui and Muiz (2020) as it focused on the impact of private accommodation on economic development of tourist destination. Also, while Chui and Muiz (2020) adopted qualitative methods in data collection and analysis, Portolan (2012) study used quantitative approach in which a survey on randomly selected sample size of 551 foreign tourists from whom data was collected. In addition, the study used semi-structured questionnaires with 20 items which covered socio-demographic characteristics, travel characteristics, stay in the destination and motivation, and tourist expenditure. However, Portolan (2012) study was not only silent on the reliability and validity of the data collection instrument but similar to a study done by Ramukhumba and Ferreira (2016) as both focused on impact made by guest house operations on local economy. However, Ramukhumba and Ferreira (2016) study on contribution of guest house on local economic development, which was based on $51.5 \%$ of 250 guesthouses and adopted quantitative methods using open and close ended questionnaires, was weak on external validity as data was mostly analyzed descriptively using frequencies and percentages. Though the studies provided useful insights in the nature, challenges and contribution of guest houses on local economies, they were apparently biased towards guest houses and did not adequately evaluate economic effect of guest house operations on the local economy in relation to hotels, restaurants and clubs.

\section{Methodology}

\subsection{Sampling and Data Collection}

The target population for the study was hotels, lodges, guest houses, restaurants and clubs which are located in Kisumu County and feature in the records of tourism regulatory authority. From a complete list of tourism enterprises which were secured from tourism regulatory authority, the enterprises were stratified into hotels and lodges, clubs and 
restaurants, and guest houses. An overall sample size of 106 was randomly drawn from the target population using Fisher`s Formulae. However, one of the observations had a missing value on one of the key variables and was excluded from the analysis. On each stratum, random sampling was applied and the sample sizes proportional to their respective subpopulation sizes were drawn. Table 1 indicates sample sizes adopted for each type of enterprise.

Table 1: Types of Enterprises and their Sample Sizes.

\begin{tabular}{lc}
\hline \multicolumn{1}{c}{ Type of Enterprise(Strata) } & Sample Size \\
\hline 1 - Hotels \& lodges & 51 \\
2- Guest Houses & 27 \\
3 - Restaurants \& Clubs & 27 \\
\hline
\end{tabular}

Questionnaires were used in data collected. The key items in the questionnaire were types of tourism enterprises, local supply frequency, and duration of local suppliers in commercial relationship with tourism enterprises, value of weekly and total supplies made by local business people, number of local suppliers engaged by tourism enterprises per week. In total 110 questionnaires were distributed but 105 were used in the study. Questionnaires were distributed physically by the researcher to each manager through front office staff and collected back after two days.

\subsection{Measures}

The comparative performance of selected tourism enterprises were measured using three key variables namely number of local businesses supplying tourism enterprises, local procurement as a proportion of all monthly procurement, and frequency of weekly procurement from local economy. The three variables were considered as correlated dependent variables in the multivariate analysis of variance. Proportion of local procurement and number of local supplier businesses were both measured on a continuous scale while frequency of local weekly procurement was measured on a 10-point Likert Scale in which 10 and 1 was highest and lowest rating respectively on a scale of 1 to 10 . The only factor in the study was category of tourism enterprises. The factor was measured at three levels which were hotels and lodges in which there were 51 enterprises in total, guest houses were 27 enterprises in total and the last level was restaurants and clubs which were 27 in total. Lastly, all the questionnaire items were originated by the researcher.

\subsection{Data Analysis}

There were two key objectives of the study: first, to find out whether tourism enterprises are significantly different in their performance in the local economy, and secondly, to analyze factors which contribute to difference in their performance. To achieve the first objective one-way multivariate analysis of variance was adopted. In the analysis, Box $M$ test was used to test homogeneity of covariance - variance matrices across categories of enterprises, Wilk`s Lamda was then adopted as an omnibus test together with $F$ test to establish significant differences across categories of enterprises. The existence of significant differences among groups of tourism enterprises necessitated the use of descriptive discriminant analysis to achieve the second objective. In discriminant analysis, Wilk's Lamda, which was approximated by Chi-square test was used to determine the number of significant dimensions 
along which the categories of tourism enterprises were significantly differentiated, and variables associated with each dimension.

\section{Results}

\subsection{Psychometric Properties}

Both face and content validity were assessed. Face validity refers to the apparent reflection of the content of the concept by a measure (Bryman and Bell, 2011), and content validity is the extent to which adequate coverage of the investigative questions has been achieved by a measure (Cooper and Schindler, 2014). The two types of validity are assessed with the assistance from the judgment of panel of experts (Bryman and Bell 2011; Cooper and Schindler, 2014). Therefore, the questionnaire used in the current study was screened for face and content validity by a panel of experts in tourism and economics department of Maseno University during proposal presentation stage. Reliability, based on internal consistency, was determined by correlating a set of questionnaire items measuring similar concept. According to Bryman and Bell (2011), internal reliability is applied to a measure with multiple indicators and Cronbach`s alpha ranging from 0.80 to 0.70 is mostly acceptable levels. In the current study, set of items in the questionnaire were assessed for reliability, and the Cronbach`s alpha was found to be 0.820 and was considered satisfactory.

A one-way multivariate of variance, based on GLM procedure, was adopted in which tourism enterprises were measured at three levels namely hotels and lodges, guest houses, and restaurants and clubs. The dependent variables were frequency of local procurement, local purchase ratio, and number of suppliers. The design was adopted in order to test whether tourism enterprises performance were different on the dependent variable.

The key assumptions of MANOVA are independence of observation of dependent variable in each category of tourism enterprises and homogeneity of variance - covariance matrices across categories of tourism enterprises and multivariate normality in dependent variables (Hahn-Vaugh, 2017). Independence of observation was fulfilled when data were collected from individual enterprises that were geographically dispersed. Homogeneity in variance covariance matrix was ascertained by Box $M$ test of equality of covariance matrix (Box $\mathrm{M}=$ $21.415, \mathrm{~F}$ value $=1.700, \mathrm{p}-$ value $=0.060)$. However, the requirement of multivariate normality was not met, but according to Hubert and Olejnik (2006) (cited in Hahn-Vaughn, 2017), MANOVA is robust to the violation when there are 20 or more cases per cell (categories of tourism enterprises). In this study, the minimum number of cases per cell was 27. Therefore, deviation from multivariate normality was not so serious at all as to invalidate the outcome of the analysis.

Discriminant analysis was used to establish factors which significantly contributed to differentiation of the tourism enterprises in their local impact on the dependent variable. According to Hahn-Vaughn (2017), discriminant analysis is the more appropriate than post hoc comparison when omnibus test on multivariate dependent variable, comprised of correlated variables, is found significant.

Table 2 indicates the result of the effect of categories of tourism enterprise on the performance of tourism business operations in local economy. From the result, it is apparent that different categories of tourism businesses are different in their operations effect on the local economy (Wilk`s lambda $=0.875, \mathrm{~F}$ - value $=2.296, \mathrm{p}-$ value $=0.036$ ).

Table 2: Multivariate Tests ${ }^{\mathrm{a}}$

\begin{tabular}{|c|c|c|c|c|c|c|c|c|}
\hline & & & & & & Partial & & \\
\hline Effect & Value & $\mathrm{F}$ & $\begin{array}{c}\text { Hypothesis } \\
\text { df }\end{array}$ & Error df & Sig. & $\begin{array}{c}\text { Eta } \\
\text { Squared }\end{array}$ & $\begin{array}{l}\text { Noncent. } \\
\text { Parameter }\end{array}$ & $\begin{array}{c}\text { Observed } \\
\text { Power }^{\mathrm{d}}\end{array}$ \\
\hline
\end{tabular}




\begin{tabular}{llrrrrrrrr}
\hline Intercept & Pillai's Trace & .914 & $352.788^{\mathrm{b}}$ & 3.000 & 100.000 & .000 & .914 & 1058.365 & 1.000 \\
& Wilks' Lambda & .086 & $352.788^{\mathrm{b}}$ & 3.000 & 100.000 & .000 & .914 & 1058.365 & 1.000 \\
& Hotelling's & 10.584 & $352.788^{\mathrm{b}}$ & 3.000 & 100.000 & .000 & .914 & 1058.365 & 1.000 \\
& Trace & & & & & & & & \\
& Roy's Largest & 10.584 & $352.788^{\mathrm{b}}$ & 3.000 & 100.000 & .000 & .914 & 1058.365 & 1.000 \\
& Root & & & & & & & & \\
Enterprise & Pillai's Trace & .128 & 2.310 & 6.000 & 202.000 & .035 & .064 & 13.862 & .794 \\
Type Factor & Wilks' Lambda & .875 & $2.296^{\mathrm{b}}$ & 6.000 & 200.000 & .036 & .064 & 13.773 & .790 \\
& Hotelling's & .138 & 2.281 & 6.000 & 198.000 & .038 & .065 & 13.683 & .787 \\
& Trace & & & & & & & & \\
& Roy's Largest & .092 & $3.091^{\mathrm{c}}$ & 3.000 & 101.000 & .030 & .084 & 9.272 & .707 \\
& Root & & & & & & & & \\
\hline
\end{tabular}
a. Design: Intercept + Enterprise
b. Exact statistic
c. The statistic is an upper bound on $\mathrm{F}$ that yields a lower bound on the significance level.
d. Computed using alpha $=.05$

Results from Table 3 shows that there were differences in average score profile on performance among the various types of tourism enterprises in terms of number of local suppliers engaged in a week, the rate at which supplies were delivered in a week and the proportion of local purchases made by the various tourism enterprises. It is observed that though hotels and lodges were above average in the number of suppliers they engage in a week, like guest houses they were below average compared to restaurants and clubs in the rate at which they ordered supplies from the local businesses in a week. Also, unlike guest houses, restaurants and clubs, hotels and lodges were below average in the proportion of their total expenditure devoted to local procurement.

Table 3: Groups Descriptive Statistics.

Valid N (listwise)

\begin{tabular}{llrrrr} 
Enterprise Type Factor & \multicolumn{1}{c}{ Mean } & Std. Deviation & Unweighted & Weighted \\
\hline Hotel \& lodge & Number of Suppliers & 5.0000 & 3.53836 & 51 & 51.000 \\
& Frequency of Weekly & 5.8824 & 2.36345 & 51 & 51.000 \\
& Supply & & & & \\
& Local Purchase Ratio & .6427 & .27660 & 51 & 51.000 \\
Guest House & Number of Suppliers & 2.9630 & 2.19232 & 27 & 27.000 \\
& Frequency of Weekly & 5.2963 & 3.02318 & 27 & 27.000 \\
& Supply & & & & 27.000 \\
Restaurant \& Club & Local Purchase Ratio & .6939 & .29297 & 27 & 27.000 \\
& Number of Suppliers & 3.8148 & 2.30446 & 27 & 27.000 \\
& Frequency of Weekly & 6.8519 & 2.83798 & 27 & \\
& Supply & & & & 27.000 \\
Total & Local Purchase Ratio & .6866 & .32031 & 105.000 \\
& Number of Suppliers & 4.1714 & 3.04914 & 105 & 105.000
\end{tabular}


Table 4 shows eigenvalues which are defined as variance of linear combination of discriminating variable and it is derived from correlation matrix of discriminating variables (Hahn-Vaughn, 2017). From the Table 4, the tourism enterprises were separated along two dimensions: They were separated along the first dimension to a greater extent (eigenvalue $=$ 0.092) and along the second dimension to a lesser extent (eigenvalue $=0.046$ ). Canonical correlation is a correlation between groups of tourism enterprises and discriminant scores (function) (Hahn-Vaughn, 2017). Squaring the canonical correlations indicates that $8.4 \%$ and $4.5 \%$ of the variance in the first and second discriminant scores or function respectively was attributed to grouping of tourism enterprises (between - group variance). Out of the total between - group variance attributed to the two discriminant functions, the first discriminant function accounted for $66.4 \%$ while the second discriminant function accounted for $33.6 \%$. Therefore, the performance of tourism enterprises in the local economy was differentiated to a greater extent along the first discriminant function.

Table 4: Eigenvalues.

\begin{tabular}{ccccc}
\hline Function & Eigenvalue & $\%$ of Variance & Cumulative \% & Canonical Correlation \\
\hline 1 & $.092^{\mathrm{a}}$ & 66.4 & 66.4 & .290 \\
2 & $.046^{\mathrm{a}}$ & 33.6 & 100.0 & .211 \\
\end{tabular}

Though tourism enterprises were expected to be differentiated along two dimensions, according to result in Table 5 below, there was only one significant dimension along which the groups of tourism enterprises were separated (Wilk`s lambda $=0.875, \chi^{2}=13.453, p-$ value $=0.036$ ).

Table 5: Wilks' Lambda.

\begin{tabular}{lcccc}
\hline Test of Function(s) & Wilks' Lambda & Chi-square & Df & Sig. \\
\hline 1 through 2 & .875 & 13.453 & 6 & .036 \\
2 & .956 & 4.582 & 2 & .101 \\
\hline
\end{tabular}

Result in Table 6 shows that the number of suppliers and local purchase ratio variable load significantly on first dimension (function1) while only frequency of weekly supply variable load significantly on the second dimension (function2). Therefore, the dimension along which the different groups of tourism enterprises are mostly and significantly differentiated is defined by the number of suppliers engaged by tourism enterprises per week and the proportion of total expenditure spent on local supplies by tourism enterprises. Likewise, the dimension along which tourism enterprises are insignificantly separated is defined by rate at which order for local supplies are made by tourism enterprises. Thus, tourism enterprises which deal with many local suppliers in a week, but whose proportion of expenditure on local procurement are lower were differentiated from the rest of the categories to a greater extent on the first discriminant function. However, tourism enterprises whose frequency of weekly procurement, sourced from many local suppliers, was higher were differentiated greatly from other enterprises on the second discriminant function. 
Table 6: Structure Matrix.

\begin{tabular}{lcc}
\hline & \multicolumn{2}{c}{ Function } \\
\cline { 2 - 3 } & 1 & 2 \\
\hline Number of Suppliers & $.955^{*}$ & .288 \\
Local Purchase Ratio & $-.273^{*}$ & .016 \\
Frequency of Weekly Supply & -.013 & $.999^{*}$
\end{tabular}

*Largest absolute correlation between each variable and discriminant function

According to Table 7 and Figure 1, hotels and lodges are differentiated from guest houses, clubs and restaurants mainly along the first dimension (Function1). However, guest houses are not completely different from restaurants and clubs when evaluated along the same dimension. Also, hotels and lodges unlike guest houses, restaurants and clubs, are significantly characterized by the higher number of suppliers engaged with in a week, but by the lowest proportion of total expenditure devoted to local procurement. This is because, as was already seen in Table 6 , the first dimension of differentiation is significantly defined by number of local suppliers engaged in a week and proportion of total expenditure devoted to local procurement. The implication of the result is that unlike other categories of tourism enterprises, hotels and lodges engage many local suppliers, but devote less of their total expenditure on local procurement. Further, restaurants and clubs are slightly superior than guest houses in relation to the number of local suppliers engaged but slightly inferior to guest houses in terms of proportion of their total expenditure devoted to local procurement. Additionally, Figure 1 and Table 7 indicates that restaurants and clubs are different from guest houses, hotels and lodges when evaluated along the second dimension which is defined significantly by the frequency of weekly supply. Thus, as compared to the other two groups of enterprises, restaurants and clubs mostly excel in the rate of weekly local procurement. Moreover, guest houses performed worse than hotels and lodges in terms of rate of local weekly procurement. However, the finding is attributed to sampling error because the second discriminant function was found to be insignificant (see Table 5; Wilks Lamda $=0.956, \chi^{2}=$ 4.582, $p$ - value >0.05)

Table 7: Functions at Group Centroids.

\begin{tabular}{lrr}
\hline Enterprise Type Factor & \multicolumn{2}{c}{ Function } \\
\hline & 1 & 2 \\
Hotel \& lodge & .304 & -.033 \\
Guest House & -.350 & -.262 \\
Restaurant \& Club & -.224 & .324 \\
Unstandardized canonical discriminant functions evaluated at group means & & \\
\hline
\end{tabular}




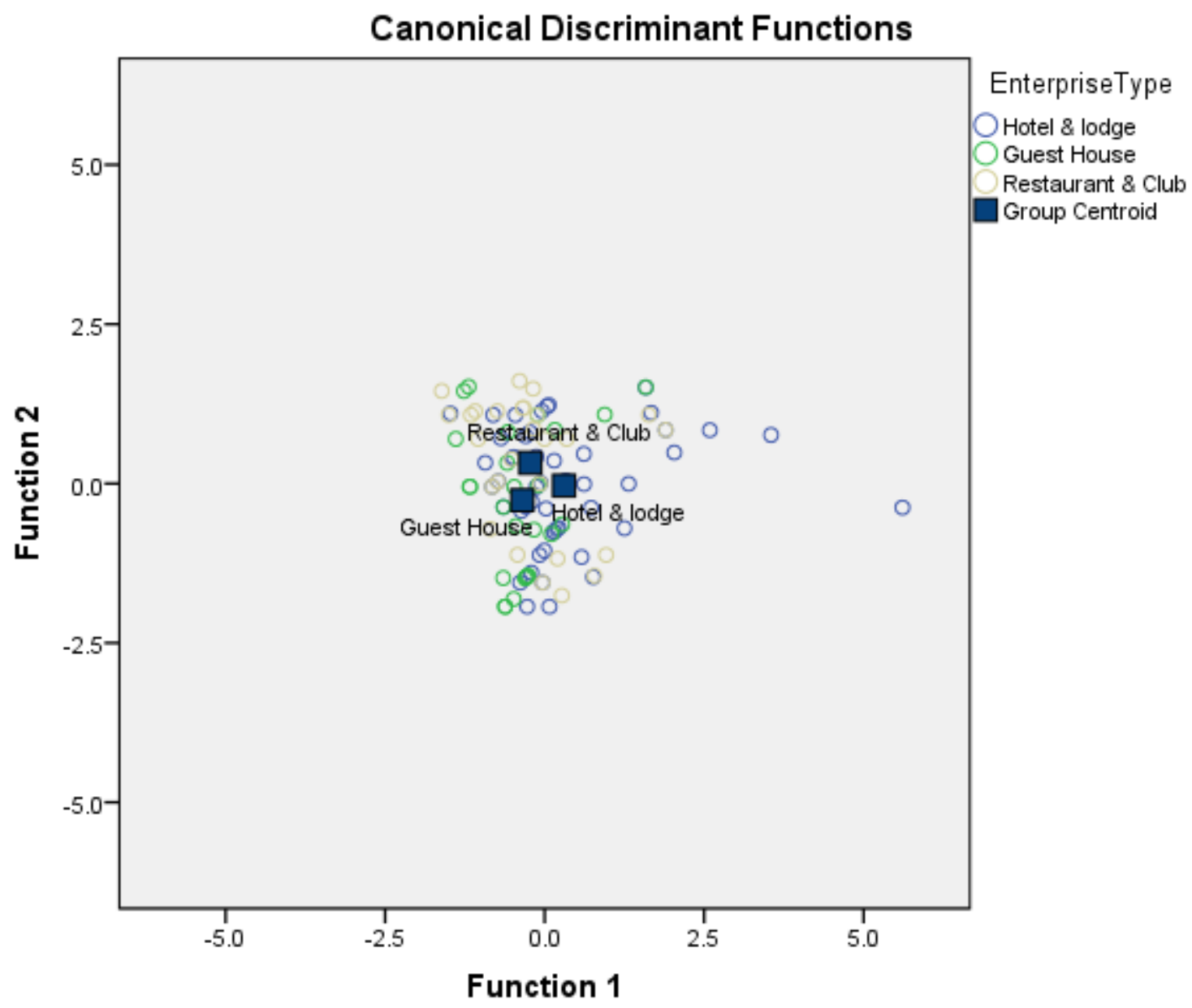

Figure1: Canonical Discriminant Functions.

\section{Conclusion, Implication, and Limitations}

This study was guided by two key objectives namely to establish whether different tourism business operations were different in performance within the local economy and secondly, to analyze factors contributing to the difference if any. One way MANOVA was adopted to establish the difference among groups of tourism enterprises and descriptive discriminant analysis was conducted in the analysis of factors contributing to their difference in performance. It has been established that tourism enterprises are different in their performance depending on their type. Hotels and lodges, guest houses, restaurants and clubs were different in performance whose indicators included the number of suppliers engaged in a week, frequency of procuring local supplies per week and proportion of total expenditure used in procuring local produce. The number of suppliers engaged per week and the proportion of total expenditure devoted to procurement of local produce significantly separated hotels and lodges from the other type of tourism business operations namely guest houses, restaurants and clubs. In other words, unlike guest houses, restaurants and clubs, hotels and lodges engage many local suppliers, but devoted less on local procurement. This confirms the previous finding that local procurement by hotels has no significant positive bearing on local poverty reduction (Rogerson \& Rogerson 2014). Also, restaurants and clubs are slightly superior to guest houses in relation to the number of local suppliers engaged but slightly inferior to guest houses in terms of proportion of their total expenditure devoted to local procurement. This supports the previous finding that majority of guest houses depend on local products (Ramukhumba \& Fereira 2016), but qualifies the finding that guest houses provide a 
source of income to local people (Zhao, 2019) to a lesser extent than restaurants and clubs. Unlike the previous studies by Magombo, Rogerson and Rogerson (2017) and Salazar (2008) which focused on role of accommodation in general on growth of tourism destination and in enhancing international competiveness respectively, the current study main focus was on differences in hotels and guest houses, restaurant and clubs in promoting local economy and the sources of such differences. Though Adiya et al. (2014) found out that accommodation sector was important in providing employment opportunities in developing countries, the current study deviate from it by comparing specific and different types of tourism enterprises in invigorating local business through rate of local procurement and number of suppliers engaged by the different tourists enterprises. In this perspective, the current study has established that tourism enterprises are differentiated by rate of their local procurements and proportion of total expenditure devoted to local produce. Lastly, Portan (2014), and Ramukhumba and Ferreira (2016) found out that private accommodation in general and guest house in particular respectively make positive economic contribution to economic development. Though this has been confirmed, the current study, additionally, has gone further to specify that, hotels and lodges supersede guest houses in terms of the number of local suppliers they engage, but performed sub - optimally in the level of expenditure that they inject into local economy.

The implication of the findings is that policies which are favorable to investment in hotels and lodges may not be significantly optimal in promoting the local economy of Kisumu County unless interventions are initiated towards diversifying local economy and boosting capacity in local production. Though hotels and lodges, on average, engage more suppliers than guest houses and restaurants, the amount of expenditure they inject in the local economy is below average. In the short run, economic welfare of local people and businesses will improve more when investments in guest houses, restaurants and clubs are encouraged because these types of enterprises devote higher proportion of their total expenditure on local procurements. Given that restaurants and clubs have the highest rate of local procurement than the other groups of enterprises; greater investment in such enterprises can strengthen the mechanism through which tourism is economically linked with local economy. Secondly, the implication from a theoretical perspective is that, in addition to the extant service profit theory which indicates that profitability and growth of an enterprise is a function of the management moderation of the joint effect of employees capability and customers`attitude, the sustainable profitability and growth is guaranteed when economic effect of a growing and profitable enterprise is significantly felt in the local economy by a careful choice of the type of tourism enterprises operating in the local economy. In other words, profitability and growth of local businesses enterprises may be mediated by competition among local enterprises and proportion of local suppliers purchased by tourism industry assuming that such local enterprises are run effectively and efficiently. Also, given efficient and efficient operations, profitability and growth of local supply businesses may be moderated by type of tourism enterprises in the local tourist industry.

The key contribution of this study is in establishing that the extents to which tourism enterprises in Kisumu County create economic linkages with local economy differ depending on the type of enterprise. Also, the study advanced knowledge on the role of accommodation sector in local economic development by revealing that though hotels and lodges mostly engage local suppliers, they devote least proportion of their budget to local procurement. Lastly, restaurants engage comparatively less local suppliers, but spent highest proportion of their budget on local procurement because of their highest rate of weekly procurement from local suppliers.

The limitation in the study was that the inferences derived from the result can only be generalized on tourism establishment found in the Kisumu County, as target population was biased towards tourism enterprises in the region. Also, the enterprises included in the study 
were only guest houses, hotels and lodges, restaurants and clubs. In light of this, future studies should consider respondents which include tour firms, airlines, national parks and apartments, randomly sampled across counties using sample size determined by effect size, level of significance and power of the test statistic. Lastly, future study should also strive to find out whether the comparative performance of tourism enterprises could be mediated or moderated or both moderated and mediated by other factors.

\section{References}

Adiya, B., Vanneste, D., Von Rompaey, A., and Ahebwa, W.M. (2014). Spatial Analysis of Tourism Income Distribution in Accommodation Sector in Western Uganda. Tourism and Hospitality Research, 14(1-2), 8-26. Doi: 10.1177/1467358414529434.

Bryman, A., and Bell, E. (2011). Business Research Methods. Great Clarendon Street, Oxford: Oxford University Press.

Chia, K.W., and Muiz, A. (2020). The Nature and Challenges of Guest House Business in Maldives: An Exploratory Study. Tourism and Hospitality Research, 0(0), 1-12. Doi: 10.1177/1467358420926688.

Christie, I., Fernandes, E., Messerli, H., and Twing - Ward, L. (2013). Tourism in Africa: Harnessing Tourism for Growth and Improved Livelihoods. Washington D.C: The World Bank.

Cooper, D., and Schindler, S.P. (2014). Business Research Method, Twelfth Edition. New York: McGraw - Hill Irwin.

Dwyer, L., and Kim, C. (2003). Destination Competitvenss: Determinants and Indicators. Current Issues in Tourism, 6(5), 369-414.

Enrst and Young, (2011). Sub - Sahara Africa Hospitality Overview. Report Prepared for the World Bank Group, Washington D.C.

Fletcher, J., Fyall,A., Gilbert,D., and Wanhill, S. (2018). Tourism: Principles and Practice, $6^{\mathrm{TH}}$ Edition. Harlow,United Kingdom: Pearson.

George, R. (2012). Managing Tourism in South Africa. Cape Town: Oxford University Press Southern Africa Ltd.

Hahs-Vaughn, D.L. (2017). Applied Multivariate Statistical Concepts. New York : Routledge. Henning, R. (2007). Effective Guest House Management. Cape Town: Juta and Company Ltd.

Heskett, J.L., Sasser, W.E., and Schlesinger, L.A. (1997). The Service Profit Chain. New York: Simon and Schuster.

Hunt, R., and Rogerson, C.M. (2013). Tourism - led Development and Backward Linkages: Evidence from Tourism - Agriculture nexus in South Africa. In G. Visser and S. Ferreira (eds), Tourism and Crisis, London: Routledge, 159-179.

Kotler, P., Bowen, T.J., and Makens, C.J.,(2014). Marketing for Hospitality and Tourism, Sixth Edition. Edinburgh Gate, Harlow: Pearson Education Inc.

Lickorish,J.L., and Jenkins,L.C. (1997). Introduction to Tourism. Oxford: Reed Educational and Publishing Ltd.

Magombo, A., Rogerson, C.M., and Rogerson, J.M. (2017). Accommodation Services for Competitive Tourism in Sub - Sahara Africa: Historical Evidence from Malawi. Bulletin of Geography. Socio - Economic Series, 38, 73-92. Retrieved from https://www.bulletinofgeography.umk.pl/.

Sharpley, R (2005). Accommodation Sector: Managing for Quality. In L. Pender and R.Sharpley.(eds), The Management of Tourism (pp.16-27). London: SAGE publications Ltd.

Marcouiller, D.W., and Xia, X., (2008). Distribution of Income from Tourism. Tourism Economics, 14(3), 545-565.

Mensah, I., and Mensah, R.D. (2013). Management of Hospitality and Tourism Services. Bloomington, Indiana: Xlibris. 
Meyer, D. (2007). Pro Poor Tourism: From Leakages to Linkages: A Conceptual Framework for Creating Linkages between Accommodation Sector and Poor Neighbouring Communities. Current Issues in Tourism, 10, 558-583.

Mshenga, P.M., and Owuor, G. (2009). Opportunities for Micro and Small Scale Businesses in Tourism Sector: The Case of Kenya Coast. KCA Journal of Business Management, 2(2), 52-68.

Ministry of Devolution and Planning. (2013). Sector Plan For Tourism 2013-2017. Nairobi: Ministry of East Africa Affairs, Commerce and Tourism.

Ministry of Labour and Human Resource Development. (2005). Sessional Paper No. 2 on Development of Micro and Small Enterprises for Wealth and Employment Creation for Poverty Reduction. Nairobi: Government of Kenya.

Nepal, S., \& Lancher, R. (2010). From leakages to linkages: Local level strategies for capturing tourism revenue in nothern Thailand. Tourism Geographies, 12(1), 77-99.

Pillay, M., and Rogerson, C.M., (2013). Agriculture - Tourism Linkage and Pro poor Impacts: The Kwa - Zulu Natal, South Africa. Applied Geography, 36, 49-58.

Portolan, A. (2012). The Impact of Private Accommodation on Economic Development of Tourist Destination - the Case of Dubrovnik - Neretva County. Oeconomica Jadertina, 1, 35-45.

Ramukumba, T., and Ferreira,I.W. (2016). Contribution of Guest House to Local Economic Development through Procurement of Locally Produced Products and Services in the Eden District Municipality, South Africa. African Journal of Hospitality, Tourism and Leisure, 5(2), 1-12.

Ritchie, J.R.B., and Crouch, J.L., (2003). The Competitive Destination: A sustainable Tourism Perspective. Wallingford: CABI.

Rogerson, J.M., and Rogerson, C.M. (2014). Maximizing the Local Development Potential of Nature Tourism Accommodation Establishment in South Africa. African Journal of Hospitality, Tourism and Leisure, 3(1), 1-20. Retrieved from http://www.ajhtl.com

Salazar, N. (2008). A Troubled Past, A Challenging Present and A Promising Future: Tanzania`s Tourism Development Perspective. Tourism Review International, 12(34), 259-273.

Torres, R., (2003). Linkages between Tourism and Agriculture in Mexico. Annals of Tourism Research, 30, 546-566.

Zhao, Y. (2019). When Guest House meet Home: The Time Space of Rural Gentrification in South West China. Geoforum, 100, 60-67.

\section{Author Biography}

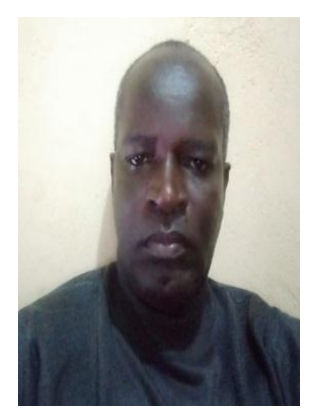

Mr. Mathias Mwalo Amata is a PhD student of Maseno University. His main areas of research interest are in tourism management, eco - tourism, tourism entrepreneurship and community participation in tourism. He has served as a tutorial fellow at Great Lakes University of Kisumu in the Department of tourism and hospitality Management. 